\title{
COMPUTATIONAL DOSIMETRY AND POST-IRRADIATION STUDIES OF THE ELECTRON BEAM IRRADIATION ASSISTED CORROSION AND STRESS CORROSION CRACKING OF STATICALLY STRAINED STEEL SAMPLES IN A SUPERCRITICAL WATER COOLANT
}

\author{
O.S. Bakai, V.M. Boriskin, M.I. Bratchenko, S.V. Dyuldya \\ National Science Center "Kharkov Institute of Physics and Technology", Kharkiv, Ukraine \\ E-mail: bakai@kipt.kharkov.ua
}

\begin{abstract}
New experimental data on the corrosion behavior of the 12X18H10T austenitic steel elastically strained coupons after $500 \mathrm{~h}$ long exposure in situ the NSC KIPT "Electron Irradiation Test Facility" supercritical water circulation loop are presented and discussed. The $\gamma$-activation analysis based computational dosimetry of samples is correlated to their weight gain/loss measurement data. The absorbed dose and stress effect on their irradiation assisted general corrosion is revealed. The corrosion surface/layer chemistry/microstructure are discussed with special emphasis of the irradiation/stress impact on the protective coating stability, intergranular corrosion and precursors of cracking.
\end{abstract}

PACS: 82.33.De;07.35.+k;29.20.Ej; 81.70.-q;61.82.Bg;81.65.Mq;68.37.-d;62.20.mt

\section{INTRODUCTION}

The Super-critical Water-Cooled Reactor (SCWR) is the next Generation IV nuclear power reactor featuring a water coolant in the state above the critical point $\left(T_{\mathrm{c}}, P_{\mathrm{c}}\right)=\left(374{ }^{\circ} \mathrm{C}, 22.1 \mathrm{MPa}\right)$ of water. Supercritical water (SCW) is a highly corrosive environment [1] for the SCWR structural materials. The database of their performance in SCW is systematically developing $[2,3]$ but is far from completion having in mind complex interplay of various driving forces of corrosion. Some of them (water chemistry, $\mathrm{pH}$ and dissolved oxygen, temperature) can be studied at out-of-pile autoclave tests. The rest (coupled $(n, \gamma)$-irradiation, coolant flow and radiolysis, thermal gradients and stress) are specific to the reactor environment and are harder to understand because of the lack and high costs of large-scale in-pile tests. The laboratory simulation experiments at dedicated facilities are thus of great value to fill this gap in knowledge of the SCWR relevant corrosion phenomena.

The NSC KIPT sited Electron Irradiation Test Facility (E.I.T.F.) contributed to this programme over the past two decades. The core of the Facility is the LEA-10 electron linac $\left(10 \mathrm{MeV} / 10 \mathrm{~kW}_{\mathrm{e}}\right)$. The E.I.T.F. features several target assemblies and techniques for corrosion tests under electron beam (EB) irradiation in situ hightemperature molten salt and aqueous corrodents. For the SCWR related tasks, the E.I.T.F. natural convection principle based Super-Critical Water Circulation Loop (SCWCL, Fig. 1) was put into operation in 2012 [4].

The pilot (2012) experiment $[4,5]$ dealt with oxidation and corrosion of high-purity $\mathrm{Zr}-1 \% \mathrm{Nb}$ and Inconel ${ }^{\mathrm{TM}}$ grade alloy 690 coupons irradiated in the vicinity of the SCWCL coolant supercritical transition. Drastic increase of the corrosion rate under irradiation (the phenomenon of Irradiation Assisted Corrosion, IAC) was first revealed for these alloys. Besides, severe Irradiation Assisted Stress Corrosion Cracking (IASCC), crevice corrosion, spallation and exfoliation were found in the highly irradiated, overheated to $460{ }^{\circ} \mathrm{C}$ and embrittled part of the austenitic stainless steel (SS) 12X1H10T made Irradiation Cell (IC) piping of the facility [5].
Sporadic Inter-Granular SCC (IGSCC) was also observed in certain Inconel ${ }^{\mathrm{TM}}$ alloy coupons in the vicinity of the base alloy 690 joint with the In52MSS weldup.

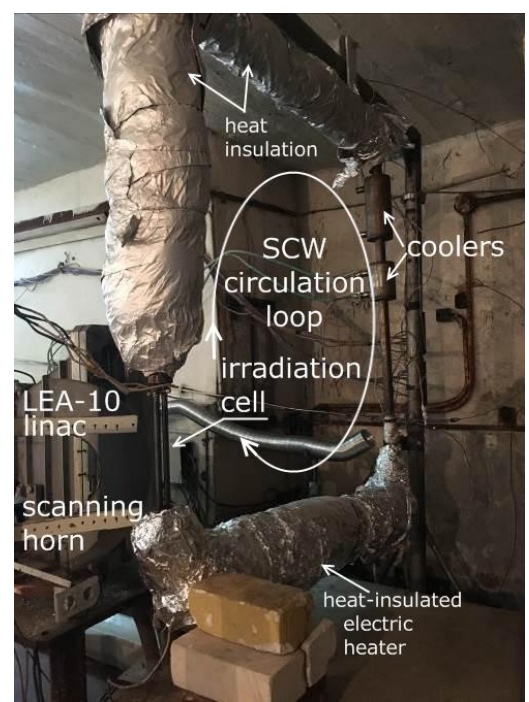

Fig. 1. The E.I.T.F. SCWCL 'Loop 1b' mounted in the LEA-10 linac shelter room. The photo had been taken before the kick-start of the 2019 irradiation experiment

The phenomenological models were proposed [6] to interpret quantitatively the observed effects by thorough calculations and multi-scale computer simulation. Particularly, SCC was attributed to the impact of residual and thermal-elastic stress. This motivated the mainstream direction of further E.I.T.F./SCWCL R\&D specifically focused on investigations of the mechanical stress impact on materials corrosion under irradiation.

An appropriate upgrade of the SCWCL IC design (see ref. [7]) has resulted in the completion (2019) of the next irradiation experiment specifically devoted to the evaluation of IAC and IASCC of SS 12X18H10T coupons in SCW under controlled static mechanical load. In this paper, we report first results of the postirradiation analysis of the obtained irradiated specimens.

The paper is organized as follows. The experimental setup, the material samples preparation and the $e^{-}$-irradi- 
ation mode details are described in Sec. 1. Novel method of the radiation field reconstruction and evaluation of the samples obtained doses is presented in Sec. 2 and applied, in Sec. 3.1, to uncover the regularities in their post-irradiation General Corrosion Test (GCT) data. The results of the corroded samples microstructure investigation are presented and discussed in Sec. 3.2.

\section{EXPERIMENTAL}

Twenty thin $(\approx 280 \mu \mathrm{m})$ rectilinear $(40 \times 9.6 \mathrm{~mm})$ coupons of the heatproof SS 12X18H10T (AISI 321), $\mathrm{Fe}_{68} \mathrm{Cr}_{18} \mathrm{Ni}_{10} \mathrm{Mn}_{2} \mathrm{Ti}_{0.7} \mathrm{Si}_{0.8} \mathrm{Cu}_{0.3} \mathrm{P}_{0.035} \mathrm{~S}_{0.02 \text { wt.\%, were placed }}$ (5 per each) inside four $\varnothing 10 \mathrm{~mm}$ tubes I-IV of the E.I.T.F. SCWCL 4-channels IC [4-6], Fig. 2.

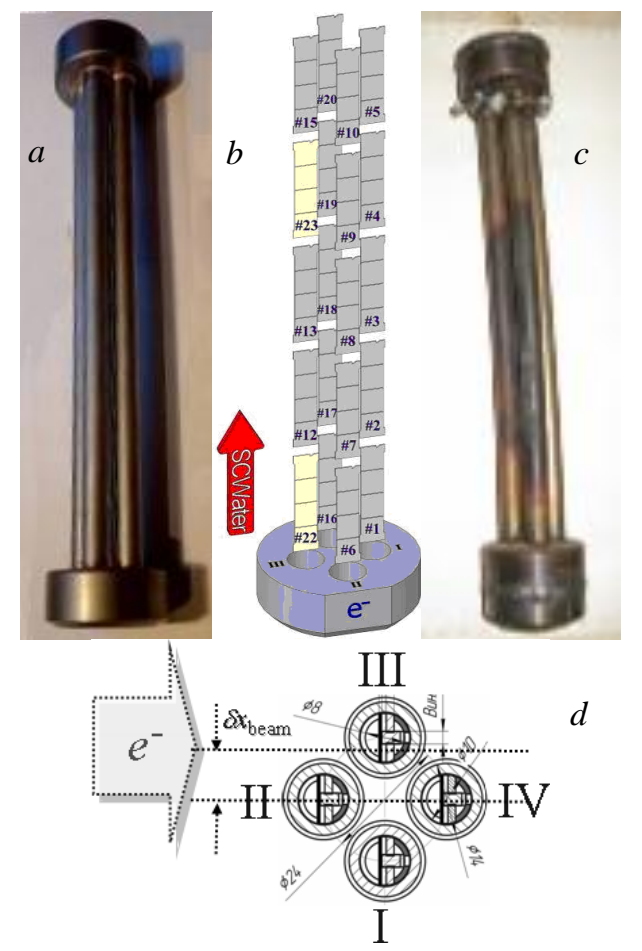

Fig. 2. The 4-channel IC before (a) and after (c) $500 \mathrm{~h}$ long EB irradiation in the SCWCL. The coupons attachment scheme is shown in $(b, d)$

Except of the coupons \#22 and 23 which were covered with $\approx 9 \mu \mathrm{m}$ thick $\mathrm{CrN}$ coatings vacuum-arc deposited from the BX1 Chromium alloy [8], all samples were equal in dimensions and composition but substantially differed in the intentionally applied static elastic stress which sprung up from the strain produced by the adjustter bolt imposed to a sample mid-span $x=0$ (for details, see ref. [7]). Coupons of length $l$ and thickness $h$ are freely edge-supported in the IC tube sample holding cassette notches (Fig. 3). This results in a triangular distribution of tensile stress $\sigma_{x x}(x)=\sigma_{\max } \cdot(1-2 \cdot|x| / l)$ [7], where $\sigma_{\max }=6 E \cdot h \cdot d / l^{2}, E$ is the Young modulus, and $d$ is the bolt controlled maximal deflection. According to the IC loading plan of Fig. 2,b, different values of $d<0.8 \mathrm{~mm}$ were used to spread $\sigma_{\max } \subset(60 \ldots 140) \mathrm{MPa}$ of coupons in the SS elasticity domain below its thermally reduced yield stress $\sigma_{0.2}=174 \mathrm{MPa}\left(400^{\circ} \mathrm{C}\right)$.

In addition, to seek for the base stress discontinuity effects, six $(3$ per side at $x \approx 0, \pm 10 \mathrm{~mm}) \approx 80 \mu \mathrm{m}$ wide $\approx 10 \mu \mathrm{m}$ deep transversal scratches were diamond cutter plotted on both convex (tensile stress $\sigma_{x x}>0$ ) and concave (compressive $\sigma_{x x}<0$ ) surfaces of each coupon.

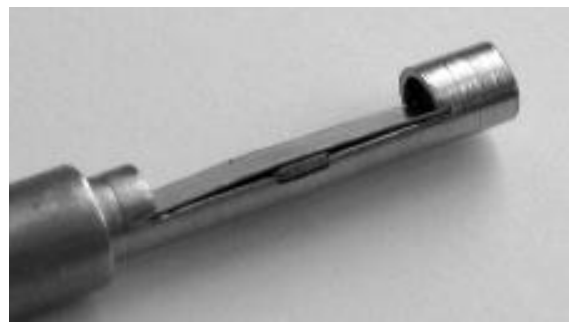

Fig. 3. The strained coupon mounted inside the IC internal sample holder with the bend adjusting screw

Finite Element Method (FEM) calculations had predicted [7] the stress concentration at a scratch bottom and close to its shoulders. It was found that the bottom located highest stress scales well with the base one: $\sigma_{\text {scratch }} \approx k_{\text {amp }} \cdot \sigma_{x x}(x)$, where $k_{\text {amp }}$ is the scratch shape dependent amplification factor. The high-resolution optical metallography cross-section digitalization of the geometry of all the scratches on samples to be irradiated was followed by a set of FEM calculations (Fig. 4). In rather good agreement with the earlier [7] predicted value of $k_{\mathrm{amp}} \approx 1.57$, they resulted in $k_{\mathrm{amp}}=1.556 \pm 0.006$ for the prepared set of specimens. Fig. 4 data show that $\left|\sigma_{\text {scratch }}\right|$ augments to $220 \ldots 240 \mathrm{MPa}$ for middle scratches of the most strained coupons (see in Fig. 2,b, this occurs for samples \#\#1, 4, 6, 9, 10, 15, 16, 19, 20, 22, $23)$, and, therefore, it is expected to exceed $\sigma_{0.2}$.

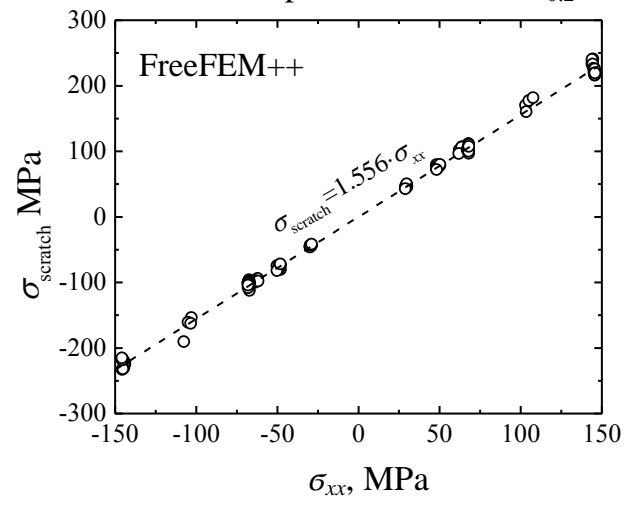

Fig. 4. The FEM calculation based estimates of the tensile/compressive stress concentration in the vicinity of the scratches plotted on the investigated coupons:

the maximal $\sigma_{\text {scratch }}$ as a function of the base $\sigma_{x x}$

The experiment was carried out in Aug.-Sep. 2019 and lasted $500 \mathrm{~h}$ of a scanning EB irradiation (in toto, incl. transients, strained coupons were exposed to a corrodent coolant for $532 \mathrm{~h}$ ). The LEA-10 linac operated at pulse duration $3.5 \mu \mathrm{s}$, pulse frequency $250 \mathrm{~Hz}$, mean energy $10 \mathrm{MeV}$, mean current $0.71 \mathrm{~mA}$ and mean power of $7.3 \mathrm{~kW}_{\mathrm{e}}$. The linac scanning magnet (saw-tooth pulses of scanning frequency $3.7 \mathrm{~Hz}$ ) shaped the vertically oblong $\approx(6 \times 19) \mathrm{cm}$ EB span on the SCWCL IC. The total fluence of $e$-irradiation amounted to $2 \cdot 10^{20} e^{-} / \mathrm{cm}^{2}$. The per-day digital records of the linac and loop parameters were stored by the facility control system to serve as raw data for further post-irradiation analysis (Fig. 5 for representative examples of these records). 
The deoxygenated distilled coolant was pressurized to $P=23.5 \mathrm{MPa}$ and freely circulated in the SCWCL driven by thermal power $Q$ inputs from both the bottomleg electrical heater and the EB power deposited in the IC tubes and internals, incl. coupons. In the experiment designing stage, System Thermal Hydraulics (STH) calculations [7] assumed the reference natural circulation scenario with $Q_{\text {heater }}=1 \mathrm{~kW}_{\text {th }}$ and $Q_{\text {beam }}=4 \mathrm{~kW}_{\text {th }}$ owing to $\approx 64 \%$ efficiency $\eta$ of the EB electric power utilization to water heating in the IC. The coolant steady-state mass-flow rate $W \approx 48 \mathrm{~g} / \mathrm{s}$ has been predicted in ref. [7]. At actual irradiation schedule, the applied mean $Q_{\text {heater }}$ was raised to $2.62 \mathrm{~kW}_{\text {th }}$ while $\eta$ has been lowered down to $\approx 55 \%$ cause of the lateral drift of the irradiation field (see Fig. 2,d and below in Sec. 2). For such inputs, STH calculations result in $W=54.3 \mathrm{~g} / \mathrm{s}$ in a reasonable $(\approx 10 \%)$ agreement with the planned scenario.

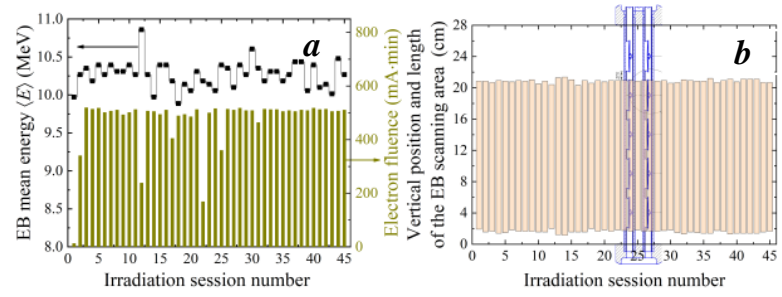

Fig. 5. Per-day records of the EB mean energy (a), electron fluence $(a)$ and the vertical position and length of the EB scanning area wrt. the SCWCL IC $(b)$

From the mass continuity considerations at the STH predicted $W$, the water coolant speed $v$ increases from 420 to $450 \mathrm{~cm} / \mathrm{s}$ along a segment between the IC inlet and outlet. However, for the samples loaded IC the open hydraulic section area reduces and the characteristic speed of coupons flow becomes about twice as large, $v \approx 1 \mathrm{~m} / \mathrm{s}$, that is well comparable with the SCWR primary-coolant circuit SCW current velocity. This is confirmed by the Computational Fluid Dynamics (CFD) simulations of the velocity field (see Fig. 9 of ref. [7]) which also made evident the $\approx$ twofold difference in $v$ near convex and concave sides of strained coupons.

In a steady-state circulation mode, the loop of the nominal (at $20{ }^{\circ} \mathrm{C}$ ) capacity of $3.81 \mathrm{~L}$ accommodated $2.45 \mathrm{~kg}$ of water of the turnover-averaged mean density $\rho \leq 0.64 \mathrm{~g} / \mathrm{cm}^{3}$. Coupled STH/Equation of State (EoS) calculations point to lower $\rho=0.58 \ldots 0.54 \mathrm{~g} / \mathrm{cm}^{3}$ at a coolant pass-through the IC. This is due to the EB induced heating and, mainly, the heat transfer from the hottest IC tubes and internals. The prescribed and the facility control system and operators sustained characteristic temperature of the coolant circulation, $T_{\text {in }}=360{ }^{\circ} \mathrm{C}$ was deliberately set smaller than both critical $T_{\mathrm{c}}=374{ }^{\circ} \mathrm{C}$ and pseudocritical $T_{\mathrm{pc}}(P)=379.5^{\circ} \mathrm{C}$ temperatures of water. It was measured by an array of thermocouples placed outside the irradiation zone (direct thermometry is problematical inside it). The STH calculations reveal the cross-section averaged temperature growth to $368^{\circ} \mathrm{C}$ before the IC outlet, and the subsequent cooling. The readings of the post-outlet thermocouples at the IC outer surface were $364^{\circ} \mathrm{C}$ for the IC channels II and III (see Fig. 2,d) and $\approx 350{ }^{\circ} \mathrm{C}$ for tubes I and IV. By and large, this agrees well with the STH prediction which also well describes possible gradual cooling of a flow by the end of weakly irradiated channels (see Fig. 9 of ref. [6]).

Generally, coolant circulated in a narrow lower vicinity of supercritical transition. However, under $e^{-}$-irradiation, the remote optical pyrometry measurements revealed temperatures of $400 \ldots 420{ }^{\circ} \mathrm{C}>>T_{\mathrm{pc}}$ at the aircooled external surface of the IC. In ref. [6], it was shown that massive IC internals also can be about $10 \ldots 15 \mathrm{~K}$ hotter then the STH predicted reference temperature of a coolant. Thus, the supercritical transition occurs just inside the IC in the vicinity of coupons, and their corrosion phenomena are determined just by the SCW flow.

The loop feedwater was of neutral $\mathrm{pH}=7,1.1 \mathrm{mg} / \mathrm{L}$ of dissolved oxygen (DO), and conductivity $\approx 20 \mu \mathrm{S} / \mathrm{cm}$. The coolant chemistry was routinely analyzed with the WTW Multi 350i device at a batcher water sampling rate $\approx 5 \mathrm{~mL} / \mathrm{min}$. Rather scattered values of (rather acidic) $\mathrm{pH} \approx(5.6 \pm 0.7)$ and $\mathrm{DO} \approx(2.9 \pm 1.4) \mathrm{mg} / \mathrm{L}$ were detecting. The conductivity grew systematically to $40 \mu \mathrm{S} / \mathrm{cm}$ and higher at a rate of $\approx 0.1 \mu \mathrm{S} / \mathrm{h}$. This argued for the increase of ionic salts content. The coolant's impurities, dirt and crud were identified using the Shimadzu ICRP9000 optical emission spectrometer. The growth of (initially absent) Chromium content to $31 \mu \mathrm{g} / \mathrm{L}$ at a rate of $0.2 \mu \mathrm{g} / \mathrm{L}$ per hour was revealed just as it had been observed in previous SCWCL runs [5]. Other elements (Fe, Mn, K, Ni, S, Ca, Mg, Si, Ti, Cu) were also found in discharged water samples. Evidently, this indicates an intense pollution of a coolant with corrosion products of both the same SS 12X18H10T made SCWCL internal surface and the coupons under investigation.

\section{COMPUTATIONAL DOSIMETRY}

The E.I.T.F. experiment attempted to reproduce the SCWR operation mode when a subcritical water coolant experiences the repeated periodical transition to SCW just inside the reactor core. The SCWCL IC serves as a core 'mock-up'. Its self-consistent description requires extensive coupled irradiation dosimetry, radiolysis, STH/CFD and FEM calculations [6] and is far beyond the scope of the current paper. Here we address only the first, dosimetry, step of this agenda's roadmap.

Its goal is the consistent calculation of the absorbed dose $D(\mathrm{~Gy}=100 \mathrm{rad})$ and primary radiation damage $N_{\text {dpa }}$ (in the number of displacements per atom, dpa) of the investigated material on a per-coupon basis. The complications arose from the uncertainty of the EB radiation field on an IC. We attempted to obtain its reconstruction using the computational dosimetry methods by means of the GEANT4.10.6 Toolkit based Monte Carlo (MC) radiation transport (RT) code RaT 3.1 which was already used by us, for similar purposes, in refs. [4-6].

The experimental bases of the MC simulation efforts were the preliminary glass photometry data (the conventional method of the LEA-10 linac beam targeting before irradiation, Fig. 6) and their a posteriori refinement wrt. the actual irradiation scenario based on the postirradiation measurements of the residual activity of irradiated coupons, the method we first propose here.

The RaT 3.1 code applied the G4EmStandard_opt3 model for simulation of electrons and bremsstrahlung 
$\gamma$-quanta transport in a realistic (Fig. 7) 3D model of the coupons loaded IC target assembly, the processes eRecoil and CoulombElastic for simulation of point defect production in atomic collisions cascades, the LLNL ENDF/B VII LEND nuclear data library for simulation of the activation induced by electro- and protonuclear reactions, the G4Radioactivation process to simulate the activity decay with time, and the MC Variance Reduction Technique (VRT) to force rare photonuclear events.

The GEANT4 G4FieldManager class was used to simulate the LEA-10 linac scanning system (see Fig. 7) for a routinely measuring EB energy spectrum having a peak at $9.3 \mathrm{MeV}$, mean energy $\langle E\rangle=10.27 \mathrm{MeV}$ and a long tail up to $17 \mathrm{MeV}$. The model took into account the scanning horn geometry, the input pencil beam size of $R_{\text {beam }}=1 \mathrm{~cm}$ and its energy dependent angular divergence $\sigma_{\text {beam }}(E)=25 \times(E /\langle E\rangle)^{2}$ mrad. The deflection of primary electrons by the magnetic field $\left|B_{x}\right| \leq 0.35 \mathrm{~T}$ was sampled based on the pulse saw-tooth shape at a $3.7 \mathrm{~Hz}$ scanning frequency. The EB scattering by the $40 \mu \mathrm{m}$ thick linac output Titanium foil was simulated as well.
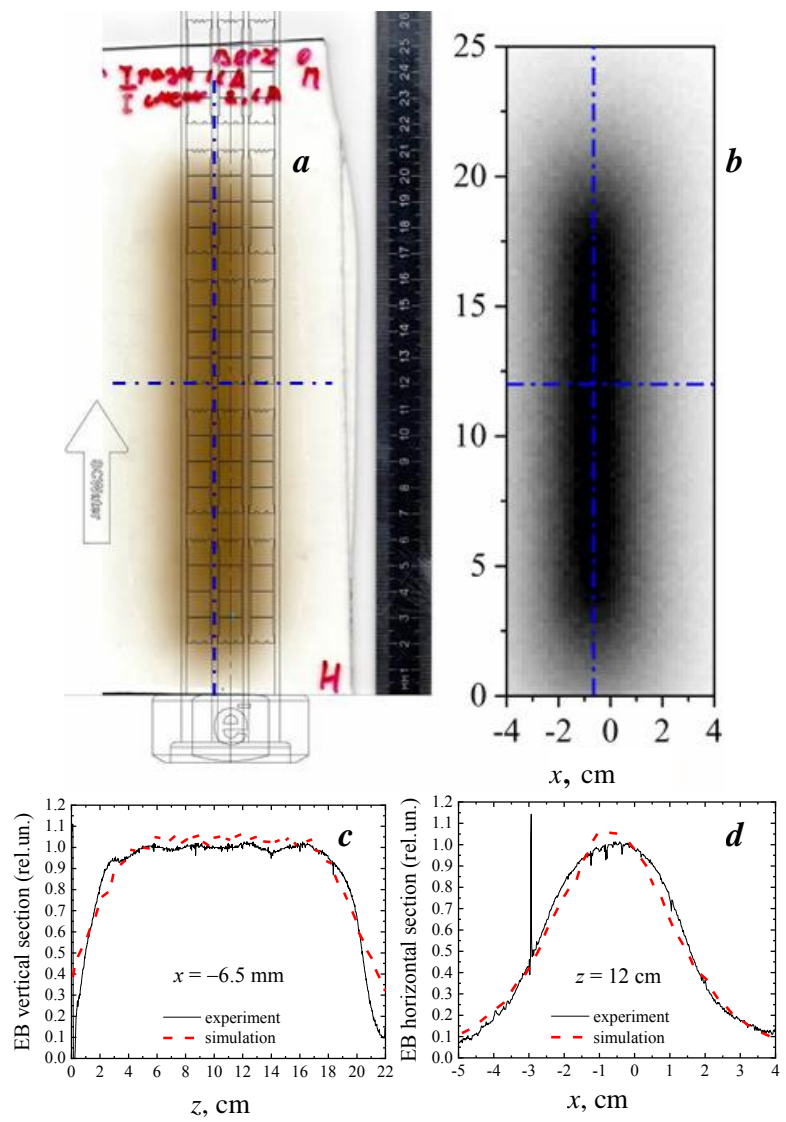

Fig. 6. The LEA-10 linac EB phase space preliminary characterization based on the glass photometry data (a) and its reproduction by the RaT 3.1 MC RT code: the absorbed dose derived glass optical density map (b) and its vertical $(c)$ and horizontal $(d)$ sections

In Fig. 6,a, it is clearly seen that the vertical symmetry axis of a beam scan is shifted, by $\delta x_{\text {beam, }}$, to the left of that of the IC (see also Fig. 2,d). This allows to decrease dose rates (and also $\gamma$-activation) in tubes I and IV and to obtain an array of low-irradiated 'witness' samples.
The preliminary simulation (see Fig. 6,b-d) pointed to $\delta x_{\text {beam }} \approx 6.5 \mathrm{~mm}$ as a best fit of the (see Fig. 6 , a) glass photometry data. However, to characterize the most probable irradiation field, required is not so much the initial $\delta x_{\text {beam }}$ as its mean value averaged over the entire $500 \mathrm{~h}$ long irradiation session. To obtain it, we proposed to use the results of activation analysis of all the coupons. It was carried out about one month after the end of irradiation session by means of the HPGe $\gamma$-spectrometer Canberra GC-2018 with fine energy resolution: $\mathrm{FWHM}=0.8 \mathrm{keV}$ at $E_{\gamma}=122.1 \mathrm{keV}$, the most intensive decay gamma line of the ${ }^{57} \mathrm{Co}$ radionuclide (half-life $T_{1 / 2}=271.6$ days) which is produced in SS via two channels of threshold $\left(E_{\gamma} \geq E_{\mathrm{th}}\right)$ photonuclear reactions: the direct one, ${ }^{58} \mathrm{Ni}(\gamma, p)\left(E_{\mathrm{th}} \approx 8.2 \mathrm{MeV}\right){ }^{57} \mathrm{Co}$, and indirect ${ }^{58} \mathrm{Ni}(\gamma, n)\left(E_{\mathrm{th}} \approx 12.2 \mathrm{MeV}\right){ }^{57} \mathrm{Ni}\left(T_{1 / 2}=35.6 \mathrm{~h}\right){ }^{57} \mathrm{Co}$.

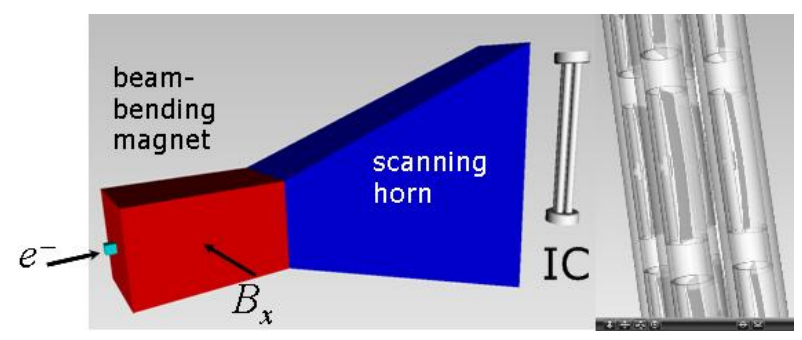

Fig. 7. The computer models of the linac scanning horn, irradiation cell and its loading with strained coupons

The raw data for coupons ${ }^{57} \mathrm{Co}$ partial activities were obtained in units relative to that of the coupon IV-3 (the $3^{\text {rd }}$ one counting from the bottom of the tube IV) in a series of about two-week separated measurements. In Fig. 8, they are plotted (as $\mathbf{X}$ ) after applying proper timeshift corrections and a normalization to the utmost values of coupons III-2,3. Other markers depict the best fit output of MC modeling obtained in a series of calculations with various $\delta x_{\text {beam }}$ the activation was found to be very sensitive to. The best fit $\delta x_{\text {beam }}=15 \mathrm{~mm}$ value differs notably from the pre-irradiation glass photometry estimate, $6.5 \mathrm{~mm}$. This is probably due to both the EB drift instabilities at the linac power control maneuvering of the SCWCL coolant circulation and the thermal-elastic distortion of the IC channels (see Fig. 2,c).

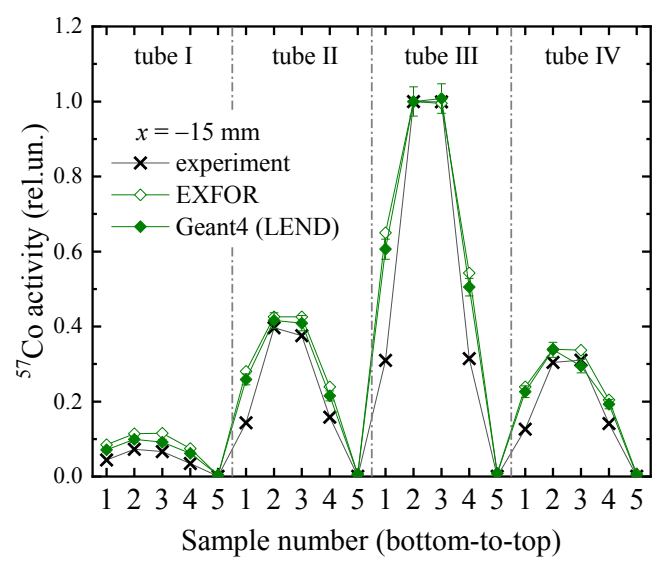

Fig. 8. The measured $(\mathbf{X}){ }^{57}$ Co relative activities of 20 irradiated coupons and their best fit reproduction by the RaT 3.1 MC code modeling for $\delta x_{\text {beam }}=15 \mathrm{~mm}$. Direct simulation of activation $(\diamond)$ and its validation using the OECD EXFOR photonuclear data $(\diamond)$ 
The obtained optimal parameters of an experimental irradiation field were applied to computational dosimetry MC calculations resulted in the Fig. 9 data. The requested variability of dosimetric quantities is clearly seen there. The irradiation load is gradually increasing in the IC channels I to III. In the tube IV, it is marginal, except of activation. Thus, the tube IV held coupons can be regarded as 'witness' samples wrt. the irradiation impact on corrosion. To a lesser extent, this also applies to the topmost samples \#5 of the generally highly irradiated tubes I-III, where the energy spectra of electrons are peaked at $\approx 6 \mathrm{MeV}$ but still have long spectral tails up to $15 \mathrm{MeV}$. Only low ( $<1 \mathrm{MeV})$ energy secondary Compton electrons are found in tube IV while the bremsstrahlung gamma flux remains significant there and is apparent in considerable activation of 'witness' samples.

The well-conditioned linear $D \propto N_{\mathrm{dpa}} \propto \Phi$ cross correlations are found in Fig. 9,b-d data. For a subsequent analysis of corrosion responses, such correlations are important to reduce the number of control variables [6].
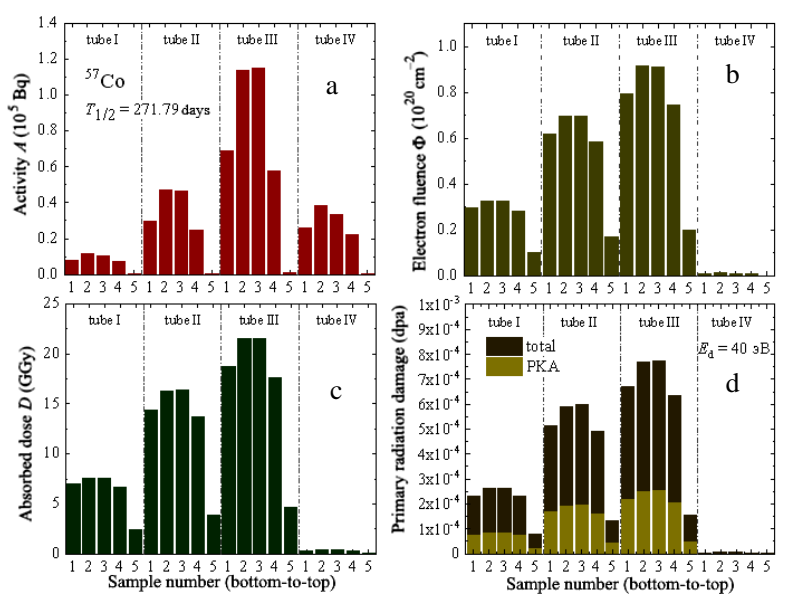

Fig. 9. The MC simulation data on the per coupon ${ }^{57} \mathrm{Co}$ activities $A(a)$, electron fluences $\Phi(b)$ absorbed doses

$D(c)$ and the primary radiation damage dpa $(d)$

No linear correlation of the uncovered electron fluence $\Phi$ and absorbed dose $D$ to the coupons' activity $A$ was found. Instead, the scaling dependency $D \propto A^{\alpha}$ was revealed (Fig. 10) with the scaling parameter $\alpha \approx 0.4$ in the EB irradiated tubes I-III and $\alpha \approx 1 / 2$ for the secondary bremsstrahlung gammas activated tube IV.

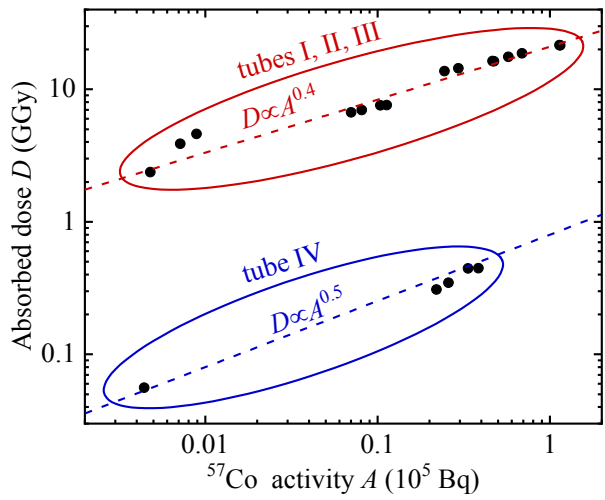

Fig. 10. The revealed power law scaling dependencies (dashed lines) of the absorbed dose $D$ and $\gamma$-activation activity $A$ of the irradiated coupons (markers)
Dose $D$ is determined by the EB energy deposition in a target. It is the $1^{\text {st }}$ order process since gamma heating is negligible wrt. the primary electrons one. In this sense, $\gamma$-activation is the $2^{\text {nd }}$ order process which is predominantly due to hard secondary photons born in the $1^{\text {st }}$ order above-threshold bremsstrahlung events (the $1^{\text {st }}$ order electronuclear reactions give only a small correction to the $\gamma$-flux induced photonuclear reactions rate due to much smaller cross-sections). The relationship between the $1^{\text {st }}$ and $2^{\text {nd }}$ order processes rates is complex and spectrally dependent. Though a simple reason for such a pronounced $D \propto A^{\alpha}$ scaling is still unclear, it seems to follow from the specifics of the E.I.T.F. experimental setup where that same target, the IC, is operating both as the EB power absorber $(D)$ and the $e^{-}$-to- $\gamma$ converter for a self-consistent $\gamma$-activation $(A)$ of its own internals, coupons. The somewhat unexpectedly obtained computational dosimetry based rule-of-thumb, "the dose in a sample is nearly proportional to the square root of the induced activity", is a valuable empirical correlation which makes it possible to evaluate the absorbed dose distribution in irradiated coupons by means of direct measurements of their residual activities.

In the upshot, it was revealed that the coupons were irradiated to $7 \ldots 22 \mathrm{GGy}(0.7 \ldots 2.2 \mathrm{Trad})$ at a rather low $\left(\sim 6 \cdot 10^{-4} \mathrm{dpa}\right)$ degree of their radiation damage. These data are juxtaposed below with those of the post-irradiation measurements of their corrosion and oxidation.

\section{POST-IRRADIATION EXAMINATION}

After completing the irradiation, coupons have been extracted from the IC channels holders, photographed (Fig. 11), and immediately weighed. All the strained coupons have retained their structural integrity without any kind of residual deformation. Thus, as predicted, the base static stress $\sigma$ under irradiation did not escape the SS domain of elasticity.

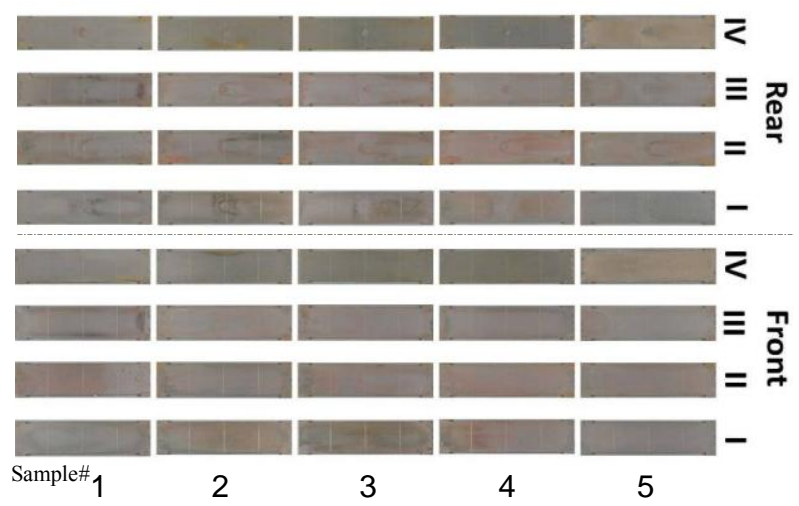

Fig. 11. Photos of the rear and front (wrt. the $e^{-}$-beam) sides of the SS 12X18H10T strained coupons after 500 h exposure to SCW under $e^{-}$-irradiation. The coolant flowed from left to right

Visually, all coupons look rusty and almost do not differ in color. Scratches on both sides have not been smoothed, albeit they are marked less clear than in the initial state. On the rear, primarily concave, sides of the samples, one can see the round spot traces of the presser bolts and the parabolic trails of the waterflow past them. It is very likely that the shapes of trails can provide data on the flow speed in close proximity to the samples. 


\subsection{IRRADIATION ASSISTED CORROSION}

The General Corrosion Test (GCT) data of Fig. 12 were obtained using the Class $2( \pm 0.025 \mathrm{mg})$ equal-arm analytical laboratory balance VLR-20 by the thrice-repeated measurements of the specific (per unit area) weight gain/loss (WG/WL) $\delta m / S=\left(m-m_{0}\right) / S$ of each coupon having masses $m_{0}$ and $m$ before and after irradiation, respectively, and a surface area $S$ of $\approx 7.154 \mathrm{~cm}^{2}$. It was found that, in average, $m_{0}=(728.17 \pm 0.74) \mathrm{mg}$, $m=(728.35 \pm 0.76) \mathrm{mg}$ except of the much heavier CrN coated coupons III-1 $\left(m_{0}=765.77 \mathrm{mg}, m=731.22 \mathrm{mg}\right)$ and III-4 ( $\left.m_{0}=764.86 \mathrm{mg}, m=731.26 \mathrm{mg}\right)$.

The GCT data of Fig. 12 look rather scattered in the lump. First, let's notice three conspicuous outliers.

Two of them concern the coated coupons III-1, 4 which exhibit the extraordinary weight losses $\delta \mathrm{m} / \mathrm{S}$ of $-484 \mathrm{mg} / \mathrm{dm}^{2}$ and $-472 \mathrm{mg} / \mathrm{dm}^{2} \quad(\delta m=-34.5 \mathrm{mg}$ and $-33.6 \mathrm{mg})$, respectively. Their post-exposure masses $m$ (731.22 and $731.26 \mathrm{mg}$ ) are close to those of uncoated, coupons, $(728.35 \pm 0.76) \mathrm{mg}$. It suggests that all the $\sim 10 \mu \mathrm{m}$ thick $\mathrm{CrN}$ coating was almost completely removed (dissolved and/or broken and delaminated) under co-operative impact of a coolant flow, $e^{-}$-irradiation to $D \approx 18 \mathrm{GGy}$, and static stress up to $\sigma_{\max } \approx 145 \mathrm{MPa}$.

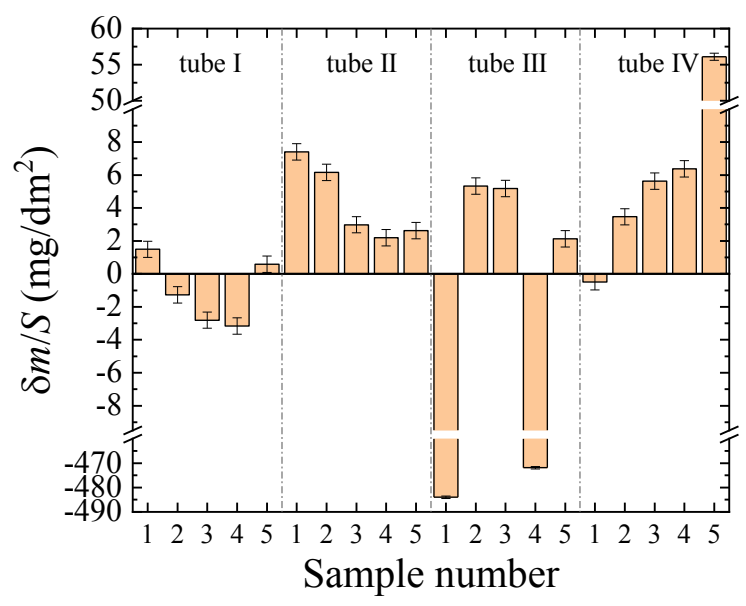

Fig. 12. The GCT measured specific weight gain (>0) or loss $(<0) \delta m / S$ of the irradiated coupons

In surface engineering, $\mathrm{CrN}$, though being prone to aging, was proven to perform as a wear-proof rust-inhibiting coating not only in normal conditions but also in $\mathrm{SCW}\left(625^{\circ} \mathrm{C}, 25 \mathrm{MPa}\right) 1000 \mathrm{~h}$ static autoclave test [10]. However, its performance in the E.I.T.F. SCWCL cannot be rated as any reasonable. It is questionable whether this is due to a certain particular drawback of the applied vacuum-arc deposition process or points to this coating limited usability in the SCWR relevant environments. Extra R\&D are definitely required.

An another outlier, the positive WG of $56.1 \mathrm{mg} / \mathrm{dm}^{2}$ $(\delta m \approx 4 \mathrm{mg})$ was measured for the poorly irradiated $(D<0.06$ GGy) coupon IV-5, the topmost sample in the 'witness' channel IV of the IC. Its particular reason is still unknown. Weight gains are generally attributed to oxidation [1-3] and appearance of pronounced (flat or rough) layers of oxides (as we observed earlier [5, 6] for $\mathrm{Zr}$ and $\mathrm{Ni}-\mathrm{Cr}$ based alloys as well as for a highly irradiated thermally stressed SS $12 \mathrm{X} 18 \mathrm{H} 10 \mathrm{~T})$. However, at $T<400{ }^{\circ} \mathrm{C}$ (see, e.g., $\left.[9,11]\right), \mathrm{Fe}-\mathrm{Cr}$ austenitic steels ty- pically show only thin volatile oxide layers and frequently tend to the weight-loss corrosion kinetics [9].

The $e^{-}$-irradiation enhanced oxidation suggests itself as the most probable reason of the WG prevalence in the Fig. $12 \delta m / S$ data. Another one can be related to the mass deposition from the corrosion products saturated SCW coolant flow (including the CRUD [12] phenomenon at the SCWCL transients). Thereupon it is worth noting that the observed irregularities of the Fig. 13 $\delta \mathrm{m} / \mathrm{S}$ data mainly occur for the edge samples \#\#1, 5 of the low-irradiated IC channels I and IV and are thus expected to correlate with the specialties of the water coolant hydrodynamics at the IC inlet and outlet.

Except of the above-mentioned outliers, the master array of the Fig. $12 \delta \mathrm{m} / \mathrm{S}$ data ranges from $-3 \mathrm{mg} / \mathrm{dm}^{2}$ to $\approx 8 \mathrm{mg} / \mathrm{dm}^{2}$ (WG of this range and $\approx 0.25 \mu \mathrm{m}$ thin oxide layers are characteristic for SS 304 and $316 \mathrm{~L}$ at $575 \mathrm{~h}$ exposure to $400{ }^{\circ} \mathrm{C} \mathrm{SCW}$ deaerated to $10 \mathrm{ppb}$ DO [11]). These data exhibit certain empirical ordering trends wrt. the sample number increase with the coupon's inlet-tooutlet position in the IC tube (see Fig. 11). They can be qualitatively correlated to those of the STH calculated coolant temperature [5-7] which is expected to increase in the EB heated channels II and III and, probably in a lesser extent, in tube I, but decreases in the 'witness' channel IV. The 'main sequence' coupons' $\delta m / S$ gradually decreases with the sample number in the irradiated channels I-III while shows an opposite growing trend in a low-irradiated tube IV. Both these regularities can be consolidated in the united trend of the GCT $\delta \mathrm{m} / \mathrm{S}$ decrease with the STH temperature of a coolant.

In average, $\langle\delta m / S\rangle=+(2.58 \pm 0.78) \mathrm{mg} / \mathrm{dm}^{2}$ for 17 coupons of the master array exposed, for $500 \mathrm{~h}$, to the SCWCL coolant $(\mathrm{pH} \approx 5.6 \pm 0.7)$ under irradiation. This is well comparable with the hydrostatic autoclave GCT data [9] on the same SS at a close (but entirely subcritical) water environment, $350{ }^{\circ} \mathrm{C}, 16.5 \mathrm{MPa}$ without irradiation. The authors of ref. [9] have built kinetic curves of $\delta \mathrm{m} / \mathrm{S}$ gradual decrease for the much longer exposure of $14000 \mathrm{~h}$. The corrosion rate was shown to be drastically affected by the coolant $\mathrm{pH}(5.0,7.2$, and 10).

Opposite to Fig. 12, no weight gain was observed in ref. [9]. Despite, we ventured to compare the magnitude $|\langle\delta m / S\rangle|$ as an indicator of the corrosion damage driving forces in both experiments. At a closest $\mathrm{pH}=5$, Fig. 1,a of ref. [9] reports $|\langle\delta m / S\rangle| \approx 2.5$ since $\approx 7500$ h of exposure (and it is only weakly changed till $14000 \mathrm{~h}$ ). In the same figure, this characteristic threshold time falls to $\approx 4000 \mathrm{~h}$ at $\mathrm{pH}=7.2$ and, at least, to well comparable $\approx 750 \mathrm{~h}$ at a highly alkaline $\mathrm{pH}=10$. One can conclude that the effective corrosion rate is 15 to 8 times greater in our experiment than in the static autoclave test [9] at comparable pH's without irradiation. The enhancement can be attributed to the IAC phenomenon we had already observed $[5,6]$ for other materials. An auxiliary gain also results from the impact of the coolant Flow Accelerated Corrosion (FAC) [2] in the SCWCL.

The particular purpose of our current experiment is the evaluation of the impact of the statically applied stress on the material corrosion under irradiation. In Fig. 13, the GCT master data array of $\delta m / S$ is plotted $v s$. the calculated (in Sec. 2) values of the total ionization 
dose $D$ absorbed in coupons. We grouped these data by the characteristic value $\sigma_{\max }$ of their tensile stress.

Three lines of Fig. 13 indicate the trends discovered in the stress grouped data using the linear Least-Square Fit procedure. The linear dose $D$ dependency of $\delta m / S$ is evident for the low-stress (60 MPa) samples; the similar (while less conditioned) one is found for the mediate stress $100 \mathrm{MPa}$. The coupons which obey each of such a linear correlation are located at the same level (3 or 2 ) in different $e^{-}$-irradiated tubes I-III; so, the coolant temperature is nearly the same for each group. Therefore, at sufficiently low stress, one observes here the isothermal linear correlation of GCT data and absorbed dose.

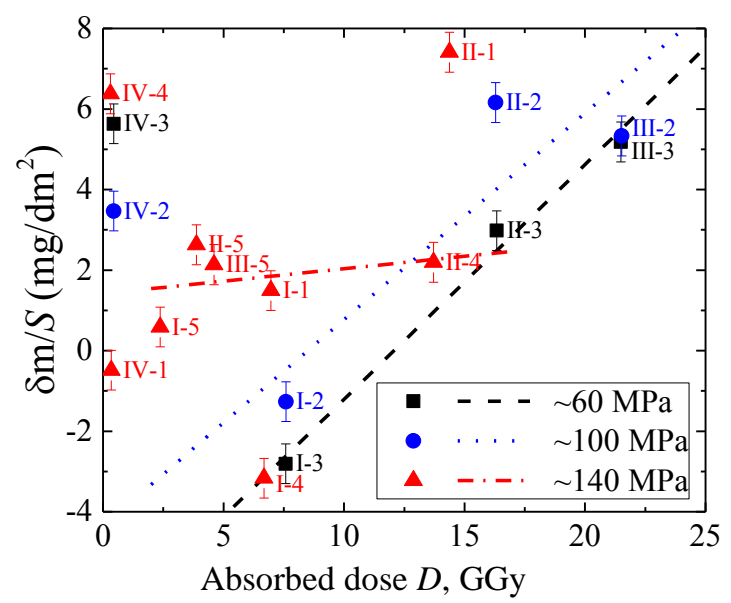

Fig. 13. The measured GCT data for coupons with different ranks of the applied stress and absorbed dose

This correlation was first revealed, for $\mathrm{Zr}-1 \% \mathrm{Nb}$ and alloy 690 oxidation, in the ref. [6] phenomenological data analysis of the previous E.I.T.F. experiment [5]. However, it is broken for a group of highly $(\sim 140 \mathrm{MPa})$ stressed coupons. For this group, Fig. $13 \delta \mathrm{m} / \mathrm{S}$ data scatter and do not follow any smooth dose dependency. This allows to make a conjecture that the applied static stress produces its own effect on a general corrosion which...

(i) $\quad .$. extends further the well studied impact of the IGSCC fracture $[2,3]$ and

(ii) ...is comparable by magnitude with the effects of IAC and temperature.

It is still too early to make final judgments about the specific nature of this effect of stress. However, suggestive considerations can go after the analytical results on the corroded samples microstructure we proceed to.

\subsection{MICROSTRUCTURAL CHANGES}

Scanning electron microscopy (SEM) imaging of corrosion surfaces (CS, Fig. 14) and cross sections was obtained using the JEOL JSM-7001F and ZEISS EVO50XVP microscopes with Oxford Instr. INCA-450 energy-dispersive spectroscopy (EDS) X-ray analyzer.

Up to date, 5 of 20 coupons from the IC channels II and III were studied: the CrN coated samples \#\#22, 23 (III-1, 4) and ordinary (uncoated) samples \#\#7, 9, 10 (II-2, 4, 5) (for nomenclature, refer to Fig. 2,b and Fig. 11).

Initially (see Fig. 14,a), the steel exhibits $\sim 1 \mu \mathrm{m}$ grains with boundaries decorated by $<0.1 \mu \mathrm{m}$ inclusions, probably carbides and oxides since the EDS de- rived chemistry points to $\approx 3$ at. $\%$ of surface oxygen. The rest is conformant to the SS $12 \mathrm{X} 18 \mathrm{H} 10 \mathrm{~T}$ nominal stoichiometry.

The post-irradiation micrographs of Fig. 14,b-d display a very developed $\sim 1 \ldots 2 \mu \mathrm{m}$ thick layer of oxidation and corrosion damage. It looks extremely rough and granular. The occasionally flat areas are scarce and limited, by size, to several microns. It is worth noting that the representative $\times 3000 \mathrm{SEM}$ micrographs of the same material's CS after the $360{ }^{\circ} \mathrm{C}$ autoclave test (see [9], Fig. 4) look similar but less disordered. Flat areas are common in ref. [9] (esp. for $\mathrm{pH}=5,7.2$ ) despite of the much longer $(14000 \mathrm{~h})$ exposure time. This agrees with the enhanced IAC in much harder conditions of the coupons' oxidation and corrosion in the SCWCL IC.
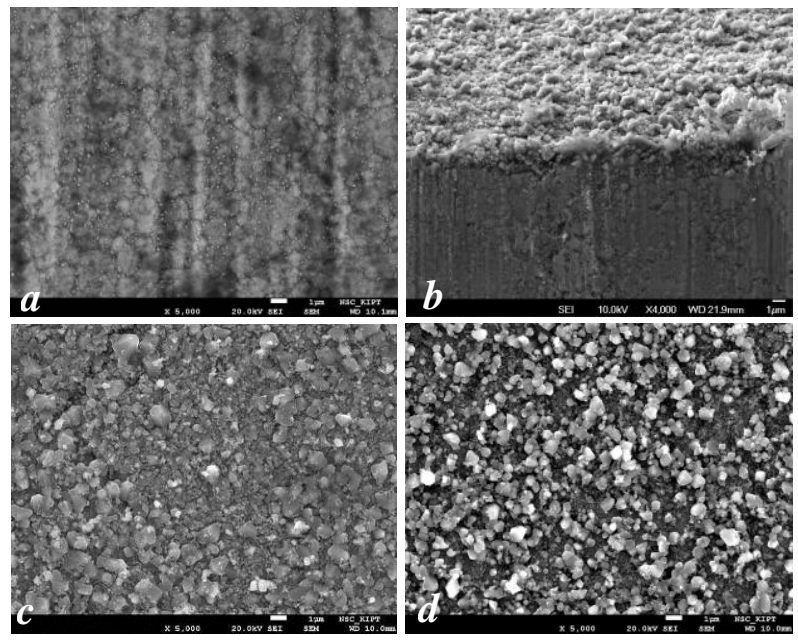

Fig. 14. SEM $(\times 5000,1 \mu \mathrm{m}$ scale bar $)$ of a steel in an initial state $(a)$, the post-irradiation $\times 4000$ SEM $3 D$

view of the sample II-2 slice (b) and the samples II-4 (c) and II-5 (d) corrosion surfaces $(\times 5000$, 1 um bar)

The SEM/EDS evaluated CS chemistry points to $\approx 45$ at.\% of oxygen and identifies the depletion of $\mathrm{Cr}$ (down to $\approx 10$ at.\% $c f$. the initial 18.6 at.\%), $\mathrm{Ni}(9 \rightarrow 6$ at.\%) and $\mathrm{Fe}(67 \rightarrow 38$ at.\%). The depositlike columnar CS morphology consists of $\sim 0.2 \ldots 2 \mu \mathrm{m}$ sized and frequently faceted grains, flakes and granules of metal oxides (magnetite, hematite, spinel and corundum-type structures) along with ferric oxyhydroxides $\mathrm{FeO}(\mathrm{OH})$ and carbides. This is peculiar to hightemperature oxidation of austenitic $\mathrm{Fe}-\mathrm{Cr}$ alloys in $\mathrm{SCW}[2,3,11]$ and is close to that observed at the earlier E.I.T.F. experiment [5].

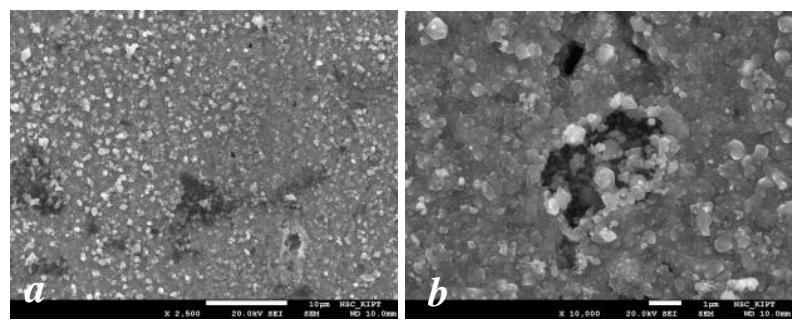

Fig. 15. SEM of the initially coated sample III-1: the $\times 2500,10 \mu \mathrm{m}$ scale bar CS overview (a) and the highresolution $(\times 10000,1 \mu \mathrm{m}$ bar) micrograph of a pit $(b)$

The characteristic post-irradiation morphology of the 
CrN coating is shown in Fig. 15. Generally, it looks as random as that of uncoated coupons (see Fig. 14,c,d) but is less covered with smaller particles. Flat regions are larger. Besides, the apparent pitting (see Fig. 15,b) of a CS results in clearly outlined $\sim 1 \mu \mathrm{m}$ deep pits occasionally filled with small $(<0.2 \mu \mathrm{m})$ granules. The CS is only slightly less $(\approx 38$ at. $\%$ ) oxidized than that of uncoated coupons but shows the substantial ( $\approx 9$ at. $\%$ ) content of nitrogen. On the X-ray EDS maps, it is spatially localized in agglomerates (the same is valid for oxygen) and in elongated 'strips'. This allows to identify the agglomerated particles as the oxynitrides $\mathrm{MeO}_{x} \mathrm{~N}_{y}$ of metals $(\mathrm{Cr}, \mathrm{Ni}, \mathrm{Fe})$ and confirms the Sec. 3.1 GCT data based conclusion that we deal only with the residues of the initial-ly dense thick $(9 \mu \mathrm{m})$ coating of $\mathrm{Cr}-\mathrm{N}$ stoichiometry.

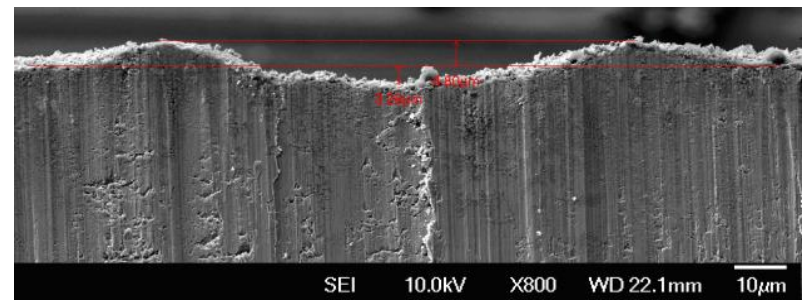

Fig. 16. The post-irradiation $x$-sectional SEM of the coupon's II-2 convex frontal surface middle scratch

Corrosion effects of the elastic tensile stress concentration on scratches were examined for the 16.3 GGy irradiated and strained to $105 \mathrm{MPa}$ coupon II-2 with a rather high $\mathrm{WG}=+6.16 \mathrm{mg} / \mathrm{dm}^{2}$. The stress-raiser scratch is shown in low $(\times 800)$ magnification in Fig. 16. It is covered by the $\sim 1 \ldots 3 \mu \mathrm{m}$ thick rough layer of oxides which is notably thinner on the scratch shoulders. The CS morphology outside the scratch and near its bottom (where the raised tensile stress $\sigma_{x x} \approx 177.5 \mathrm{MPa} \cong \sigma_{0.2}$, see Fig. 4) is presented in Fig. 17, respectively.

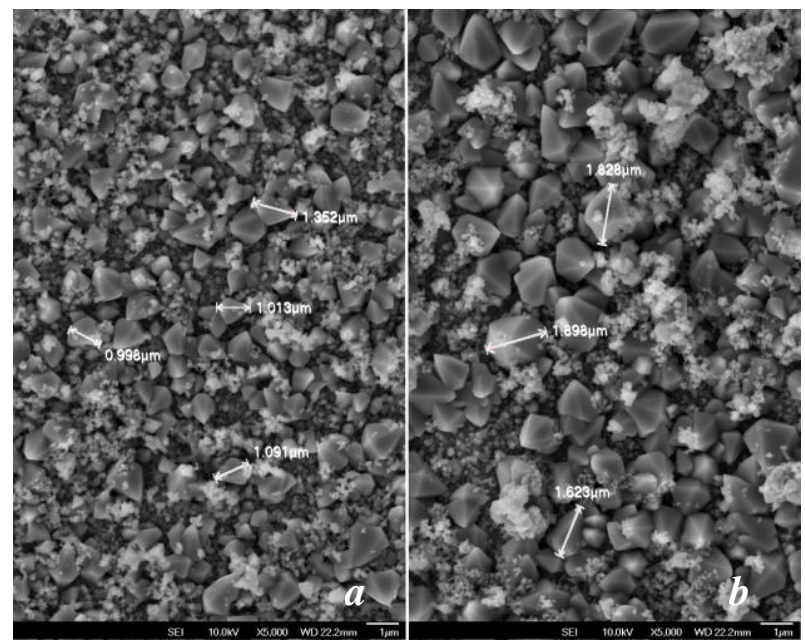

Fig. 17. The coupon II-2 CS SEM $(\times 5000,1$ um scale bar) 150 um away from the scratch (a) and inside it (b)

The equal-area CS morphologies of Fig. 17 are generally similar by structure $(<1 \mu \mathrm{m}$ sized particles $)$ and chemistry (large grains are mainly of hematite $\mathrm{Fe}_{2} \mathrm{O}_{3}$ ). However, about twofold as large $(\sim 2 \mu \mathrm{m})$ particles are observed more frequently near the scratch bottom. It can result from the stress enhanced intergranular oxidation and etching of grain boundaries followed by chemical transformation of etched grains into ferric oxide granules. An intergranular corrosion and sporadic appearance of the stress promoted crack nucleation are seen in Fig. 18. The characteristic distance between the oxygen decorated grain boundaries in Fig. 18,b is nearly the same as the size of largest particles in Fig. 17,b.

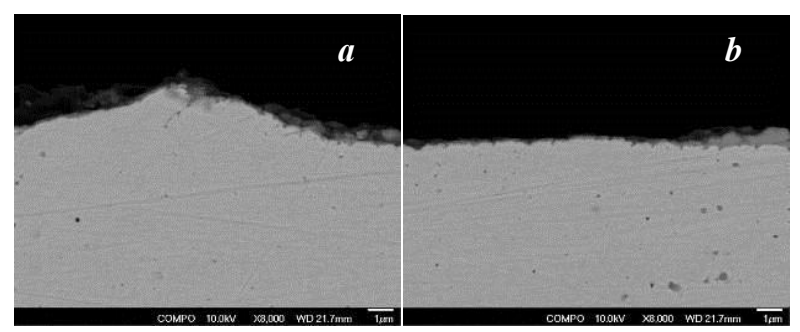

Fig. 18. The compositional contrast (COMPO, $\times 8000$,

1 um scale bar) SEM of the scratch shoulder (a) and bottom (b) with the traces of intergranular oxidation (b) and crack nucleation (a) at stress risers

Here we observe only a weak tendency of a material to IGSCC by the stress enhanced crack nucleation (see Fig. 18,a) while much more pronounced SCC precursors had been revealed in ref. [5] for the same material in more severe conditions of crevice corrosion, higher temperatures and differently distributed mechanical loading. To study the material tolerance to the IASCC within the currently developed controllable technique, supplementary factors are appropriate, e.g., the simulation of fatigue effects through the in situ application of cyclic mechanical treatment. The works are in progress.

\section{ACKNOWLEDGEMENTS}

This work was carried out at the expense of the budget program "Support for the Development of Priority Areas of Scientific Research" (КПКВК 6541230).

\section{REFERENCES}

1. P. Kritzer. Corrosion in high-temperature and supercritical water and aqueous solutions: a review // $J$. of Supercritical Fluids. 2004, v. 29, p. 1-29.

2. T.R. Allen, Y. Chen, X. Ren, K. Sridharan, L. Tan, G.S. Was, E. West, D. Guzonas. Material performance in supercritical water / R.J.M. Konings (Ed.) Comprehensive nuclear materials, v. 5. Elsevier Ltd. Amsterdam, Netherlands, 2012, p. 279-326.

3. D. Guzonas, R. Novotny, S. Penttila, A. Toivonen, W. Zheng. Materials and water chemistry for Supercritical Water-Cooled Reactors. Woodhead Publ. Ser. in Energy, Elsevier UK Ltd., Cambridge, 2018, 264 p.

4. A.S. Bakai, V.N. Boriskin, A.N. Dovbnya, S.V. Dyuldya, D. Guzonas. Supercritical Water Convection Loop for SCWR materials corrosion tests under electron irradiation: First results and lessons learned // Proc. of the $6^{\text {th }}$ Int. Symp. on SCWR's (ISSCWR-6), March 3-7, 2013, Shenzhen, Guangdong, China. Paper \#ISSCWR6-13062, 14 p.

5. O.S. Bakai, V.M. Boriskin, A.M. Dovbnya, S.V. Dyuldya, D.A. Guzonas. Combined effect of irradiation, temperature, and water coolant flow on corrosion of $\mathrm{Zr}-$, Ni-Cr, and Fe-Cr-based alloys // J. Nucl. Eng. Rad. Sci. 2016, v. 2, issue 1, 021007, 11 p. 
6. O.S. Bakai, V.M. Boriskin, M.I. Bratchenko, S.V. Dyuldya. $e$-Irradiation, temperature, and stress effect on corrosion of $\mathrm{Zr}-, \mathrm{Ni}-\mathrm{Cr}$-, and $\mathrm{Fe}-\mathrm{Cr}$-based alloys near the water coolant supercritical transition // PAST. Series "Vacuum, Pure Materials, Superconductors". 2020, N 1(125), p. 68-77.

7. A.S. Bakai, V.N. Boriskin, M.I. Bratchenko, R.N. Dronov, S.V. Dyuldya, Yu.V. Gorenko, S.V. Shelepko. The cell for electron irradiation of stressed steel samples in a supercritical water flow for corrosion evaluation // PAST. Series "Nucl. Phys. Investigations". 2019, N 6(124), p. 172-180.

8. В.В. Кунченко, А.А. Андреев, Ю.В. Кунченко, Г.Н. Картмазов. $\mathrm{CrN}_{\mathrm{x}}$-покрытия, полученные вакуумно-дуговым методом // ВАНТ. Серия «ФРП и PM». 2004, № 3(85), с. 87-95.

9. В.С. Красноруцкий, И.А. Петельгузов, В.М. Грицина, В.А. Зуёк, М.В. Третьяков, Р.А. Рудь, Н.В. Свичкарь, Е.А. Слабоспицкая, Н.И. Ищенко.
Коррозия нержавеющих сталей в условиях, имитирующих теплоноситель первого контура реакторов ВВЭР-1000. Коррозионное поведение смешанных загрузок топлива // ВАНТ. Серия «ФРП и РМ». 2011, N 2(72), c. 80-87.

10. R. van Nieuwenhove, J. Balak, A. Toivonen, S. Penttila, U. Ehrnsten. Investigation of coatings, applied by PVD, for the corrosion protection of materials in supercritical water // Proc. of the $6^{\text {th }}$ Int. Symp. on SCWR's (ISSCWR-6), March 3-7, 2013, Shenzhen, Guangdong, China. Paper \#ISSCWR6-13024, 12 p.

11. G.S. Was, S. Teysseyre, Z. Jiao. Corrosion of austenitic alloys in supercritical water // Corrosion. 2006, v. 62, issue 11, p. 989-1005.

12. S. Cassineri, J. Duff, M. Curioni, A. Banks, F. Scenini. CRUD deposition in accelerated hightemperature water: Investigation on the effect of substrate material and water chemistry // JNM. 2020, v. 529 , p. 151915.

\title{
ВЫЧИСЛИТЕЛЬНАЯ ДОЗИМЕТРИЯ И ПОСЛЕОБЛУЧАТЕЛЬНЫЕ ИССЛЕДОВАНИЯ СТИМУЛИРОВАННЫХ ЭЛЕКТРОННЫМ ОБЛУЧЕНИЕМ КОРРОЗИИ И КОРРОЗИОННОГО РАСТРЕСКИВАНИЯ ПОД НАПРЯЖЕНИЕМ СТАТИЧЕСКИ ДЕФОРМИРОВАННЫХ ОБРАЗЦОВ СТАЛИ В СВЕРХКРИТИЧЕСКОМ ВОДНОМ ТЕПЛОНОСИТЕЛЕ
}

\author{
А.С. Бакай, В.Н. Борискин, М.И. Братченко, С.В. Дюльдя
}

Приведены и обсуждаются новые экспериментальные данные по коррозионному поведению упругодеформированных купонов аустенитной стали 12X18Н10Т после 500-часовой экспозиции in situ сверхкритической водной конвекционной петли установки «Electron Irradiation Test Facility» ННЦ ХФТИ. Основанные на $\gamma$-активационном анализе данные вычислительной дозиметрии образцов сопоставлены с данными измерений набора или потери ими массы. Выявлено влияние поглощенной дозы и напряжения на их стимулированную облучением общую коррозию. Состав и микроструктура коррозионной поверхности и слоя обсуждаются с особым вниманием к влиянию облучения и напряжения на стабильность защитного покрытия, межзеренную коррозию и предвестники растрескивания.

\section{ОБЧИСЛЮВАЛЬНА ДОЗИМЕТРІЯ ТА ПІСЛЯОПРОМІНЮВАЛЬНІ ДОСЛІДЖЕННЯ СТИМУЛЬОВАНИХ ЕЛЕКТРОННИМ ОПРОМІНЕННЯМ КОРОЗІЇ ТА КОРОЗІЙНОГО РОЗТРІСКУВАННЯ ПІД НАПРУГОЮ СТАТИЧНО ДЕФОРМОВАНИХ ЗРАЗКІВ СТАЛІ В НАДКРИТИЧНОМУ ВОДНОМУ ТЕПЛОНОСІї}

\author{
О.С. Бакай, В.М. Борискін, М.І. Братченко, С.В. Дюльдя
}

\begin{abstract}
Наведені та обговорюються нові експериментальні дані щодо корозійної поведінки пружно деформованих купонів аустенітної сталі 12Х18Н10Т після 500-годинної експозиції in situ надкритичної водної конвекційної петлі установки «Electron Irradiation Test Facility» ННЦ ХФТІ. Засновані на $\gamma$-активаційному аналізі дані обчислювальної дозиметрії зразків зіставлені з даними вимірів набуття або втрати їх маси. Виявлений вплив поглиненої дози та напруги на їх стимульовану опроміненням загальну корозію. Склад та мікроструктура корозійної поверхні та шару обговорюються з особливою увагою до впливу опромінення й напруги на стабільність захисного покриття, міжзеренну корозію та передвісники розтріскування.
\end{abstract}

